\title{
自然室温時における室内温熱環境の統計的解析 \\ 実験用実大アトリウム内の温熱環境解析その 2
STATISTICAL ANALYSIS OF INDOOR THERMAL ENVIRONMENT FOR NATURAL CONVECTION CASES \\ Study of thermal environment in real-scale atrium (Part 2)
}

\section{平松徹也*, 原田岡**, 加藤信介 ${ }^{* * *}$, 村上周 三****, 吉野 博***** Tetsuya HIRAMATSU, Takeshi HARADA, Shinsuke KATO, \\ Shuzo MURAKAMI and Hiroshi YOSHINO}

We have studied thermal environment in real-scale atrium.

The heat budget of the room air and each surface of the indoor walls are examined from the measured temperature and so on. The room temperature is analyzed with the macro model. The following conclusion are obtained.

(1) The error of total heat budged was about 5 percent of the total solar incident, so that the data obtained here are very effective to verify the mathematical analysis.

(2) The heat gain from the structural frames is a very important factor for designing the atrium's indoor environment.

\section{KEYWORDS : Atrium, Thermal environment, Long term measurement, Heat budget analysis}

アトリウム、温熱環境、長期実測、熱収支分析

1. はじめに

種々の明確な境界条件のもとで、実験用実大アトリウムの室内温 熱環境を長期にわたり実測し、その性状に関し統計的解析を行っ た。本研究の目的は第 1 にアトリウム室内環境の設計上重要な因子 について系統的、かつ定量的に検討し、今後のアトリウム空間内の 環境計画の基礎資料として整備することである。また、第 2 に数值 解析手法の検証に用いる精度の高い測定値のデータベースを整備す ることである。

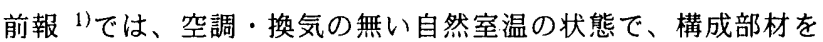
種々変更した時の日射取得、及び室内温熱環境について報告した。 本報では、これら自然室温時の実験結果の熱収支を統計的に検討 し、更に簡易モデルによる温度分布計算を実施し、構成部材が温熱 環境に与える影響について定量的な解析を行った。また、熱収支分 析・温度計算に使用される熱伝達係数の感度分析も行ったので、併 せて報告する。次報では空調時、自然換気時の室内温熱環境の分析 結果について報告する予定である。なお、国際共同研究 IEA Annex26 委員会では本報告の測定結果を用い、各国の研究グルー プの温熱環境の数値解析手法を比較検証している2)。本研究で得ら れた結果はこれらの数值解析結果を検証する際に特に重要となる。

\section{2. 実験}

実験用実大アトリウムの仕様、測定条件、測定項目の詳細につい

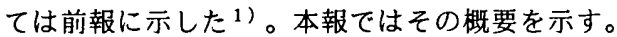

\section{1. 測定条件}

図 1 に示す間口 $7.0 \mathrm{~m} \times$ 奥行き $4.3 \mathrm{~m} \times$ 高さ $4.5 \mathrm{~m}$ の実大規模の実験 用アトリウムを用い、自然室温時の室内の温熱環境測定を実施し た。実験条件の概要を表 1 に示す。表のようにガラス種類、北壁・ 床の色、屋根の有無などを変化させ、これら構成部材が室内温熱環 境に与える影響を検討した。CASE 1,2,4,5 は東西南、屋根の 4 面

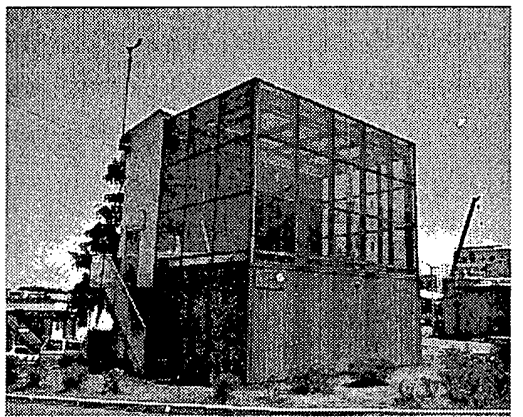

図 1 アトリウム実験棟の外観

\footnotetext{
本論文は参考文献3),4)の内容に新たな解析と考察を加えてまとめたものである。

* 旭硝子株式会社硝子建材事業本部 主任技師. 工博

** 旭硝子秼式会社硝子建材事業本部技術開発部 主幹技師

Flat Glass \& Construction Materials General Div., Asahi Glass Co., Ltd., Dr. Eng. Principal Engineer, Technology \& Development Div., Flat Glass \& Construction Materials General Div., Asahi Glass Co., Ltd.

*** 東京大学生産技術研究所 助教授 $\cdot$ 工博

**** 東京大学生産技術研究所 教授. 工博

Assoc. Prof., Institute of Industrial Science, University of Tokyo, Dr. Eng.

Prof., Institute of Industrial Science, University of Tokyo, Dr. Eng.

***** 東北大学工学部建築学科 教授. 工博

Prof., Dept. of Architecture, Faculty of Engineering, Tohoku University, Dr. Eng.
} 
表 1 測定時期と実験条件

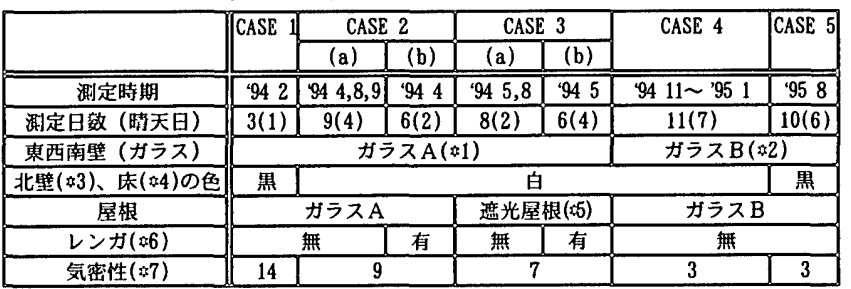

ง1. 细入板ガラス $(6.8 \mathrm{~mm}$ 草 $)+$ 熱缐反射フィルム

:日射透過率: 0.37 、日射吸収率 (屋外側入射) $: 0.33$

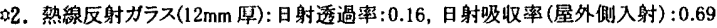

83. 合板 $(10 \mathrm{~mm}$ 厚) + 断熱材 $(100 \mathrm{~mm})$ 日射吸收率: 0.96 (黒)、0.15 (白)

4. 合板 $(5.5 \mathrm{~mm}$ 厚) +断熱材 $(50 \mathrm{~mm})$ 日射吸収率: 0.96 (黒)、0.15 (白)

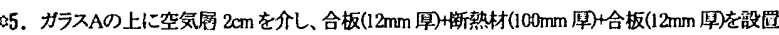

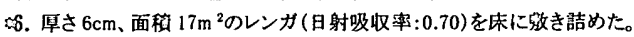

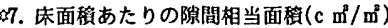

表2 室内咉骨、サッシュの分布

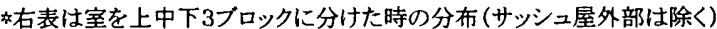

\begin{tabular}{|c|c|c|c|c|c|c|c|}
\hline & $\begin{array}{c}\text { 表面称 } \\
\left(\mathrm{m}^{2}\right)\end{array}$ & $\begin{array}{l}\text { 容稍 } \\
\left(\mathrm{m}^{3}\right)\end{array}$ & $\begin{array}{l}\text { 熱容量 } \\
(\mathrm{M} / / \mathrm{C})\end{array}$ & & $\begin{array}{c}\text { 表面称 } \\
\left(\mathrm{m}^{2}\right)\end{array}$ & $\begin{array}{l}\text { 容称 } \\
\left(\mathrm{m}^{3}\right)\end{array}$ & $\begin{array}{l}\text { 熟容指 } \\
(\mathrm{M} / / \mathrm{C})\end{array}$ \\
\hline サッシニ (屋外) & - & 0.05 & 0.2 & 上段 & 52 & 0.24 & 0.8 \\
\hline サッシュ(屋内) & 17 & 0.07 & 0.2 & 中段 & 10 & 0.09 & 0.3 \\
\hline 柱 & 24 & 0.20 & 0.7 & 下段 & 10 & 0.16 & 0.5 \\
\hline 梁 & 24 & 0.15 & 0.5 & 部 & 72 & 0.49 & 1.6 \\
\hline トラバース装圆 & 7 & 0.07 & 0.2 & & & & \\
\hline 話 & 72 & 0.54 & 18 & & & & \\
\hline
\end{tabular}

表3 蓄熱計算に用いた各部位に熱容量 $\left(\mathrm{kJ} /{ }^{\circ} \mathrm{C} \cdot \mathrm{m}^{2}\right)$

\begin{tabular}{|c|c|c|c|}
\hline & 床 & 北壁 & ガラス \\
\hline CASE1,2(a),3(a) & 3.9 & 8.5 & 20.6 \\
\hline$-\mathrm{CASE2}(\mathrm{b}), 3(\mathrm{~b})$ & 40.9 & $8 . \overline{5}$ & 20.6 \\
\hline CASE $4 \sim 5$ & 3.9 & 8.5 & 30.1 \\
\hline
\end{tabular}

をガラスとした基本的な実験ケースである。ここではガラス、及ひ 壁・床材料の光学特性の影䈏を検討した。ガラスの日射透過率は CASE 1,2 では 0.37、CASE 4,5 では 0.16 である。北壁・床の色は CASE 1,5 では黒色、CASE 2，4では白色である。

CASE 3 は室内への入射日射を低減するため、屋根ガラス上に遮光断 熱板を設置した実験ケースである。屋根以外の構成部材は CASE2 と同 様とした。

また CASE 2、CASE 3 では熱容量の影䆏を検討するため、床面に 厚さ 6c⿴、面穦 17 口 2 のレンガを敨いた実験ケースも実施した (CASE2-(b)、CASE3-(B))。

\section{2。淈定項目}

気象条件として(1)水平面全天、天空日射量、(2)外気温、隊室・床 下温度、(3)外気風向風速を測定した。室内温熱環境に関し、(4)室温 （27 点）、(5)壁表面温度（42 点）、(6)ガラス面透過日射量、(7)北壁 面中央部の㫟直面入射日射酉、8)室内鉄骨表面温度（3 点）を測定 した。日射冒測定には綪密全天日射計（英弘綪機社製）、気温、表 面温度測定には線径 0.2 四の $\mathrm{T}$ 型熱電対を用いた。

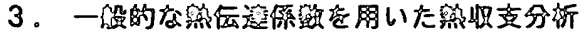

実測結果を用い、室内熱收支胜状を分析した。解析の際、熱伝達 係数は建築設計分野で一般的に使用されるものを用い、室内鉄骨。 サッシュの取り扱いに関しても、単純化を試みた。目的は実測の妥 当性の確認、すなわち效值解析手法の検証用データとして、実測結 果が有効であるか、否かの検証である。熱伝達係效の与え方、種々 現象の単純化の方法は、アトリウム温熱環境を数傎解析する際の参 考資㪴になると思われる。また本章の解析結果を用い、4．3．節 では構成部材による熱収支特性の違いを検討する。

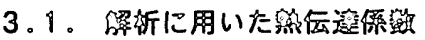

計算に用いた室内側対流熱伝達係数、屋外総合熱伝達係数はそれそ れ、Wilkes、Rowley による実験值 ${ }^{5)}$ で次式で表される。

- 室内側対流熱伝達係数

(単位 $\mathrm{W} / \mathrm{m}^{2} \cdot \mathrm{K} 、 \Delta \boldsymbol{\imath}$ は壁・空気温度差)

$\alpha_{c i}= \begin{cases}3.5+4.7 \cdot 10^{-2} \cdot \Delta t+3.5 \cdot 10^{-4} \cdot \Delta t^{2} & \text { (鉛直面) } \\ 5.8+2.7 \cdot 10^{-2} \cdot \Delta t+7.6 \cdot 10^{-3} \cdot \Delta t^{2} & \text { (水平面上鼠流) } \\ 2.2 \text { (水平面下降流) } & \end{cases}$

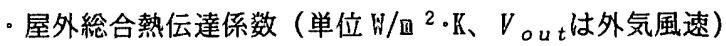

$\alpha_{\text {out }}=9.3+35 \cdot V_{\text {out }}$

屋外総合熱伝達係数は(2)式のように外気風速に依存するが、本 解析では、全測定時の平均風速 $2.3 \mathrm{~m} / \mathrm{s}$ に対応する $17.4 \mathrm{H} /$ 田 $^{2} \cdot \mathrm{K}$ に 固定して铪討した。

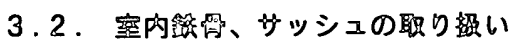

当アトリウムでは、ガラス表面積の約 1 割をサッシュ（鉄製悹 枿）か占め、屋内には柱、梁、気流測定用トラバース装置など、容

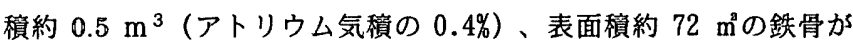
ある。表 2 に室内鋯骨、サッシュの分布状況の概要を示す。

室内鉄骨・サッシュは、特に日射が当たる状況で、以下の 3 点 において室内温熱環境に影響を与えると考えられる。これらの影響 に対する本研究の取り扱いを併せて示す。

(1)ガラス面、北壁・床面の日射取得量への影䑶

柱、梁は各ガラス面の近傍に配置されており、そのガラス面への 投影面䆅は各ガラス面穞の約 $25 \%$ にたる。本研究では、室内への 入射光はサッシュ、柱、梁により $25 \%$ 遮倳され、ガラスの室内側反 射率も見かけ上 $25 \%$ 低減すると仮定した（鉄骨の日射反射率を無 視）。ガラス面の吸収日射量は、ガラス（面稆分率 0.9）とサッシュ （面稳分率 0.1、日射吸收率 0.9）の吸収日射冝の和として評価した。 日射置計算方法は前報 ${ }^{1)}$ に示した通りである。計算において、直 達光、拡散光の寄与に分け、ガラス光学特性の入射角依存性を考虑 し、室内の完全相互拡散反射を仮定している注 1 。

(2)放射場への影偣、室内空気加熱への影䊀

日中、日射により加熱された鉄骨は、放射場へ影響を与え、室内 空気を加熱する。各壁面（曺西南、屋根ガラス、北壁、床）の長波 放射取得計算注2では、鉄骨、サッシュの影疃を無視した。室内鉄骨 から空気への対流熱伝達量は、表 2 のように鉄骨表面積を上中下ブ ロックにそれそれ 52、10、10 $\mathrm{m}^{2}$ 振り分け、その寄与を評価した。 鉄骨表面の対流熱伝達係数はWilkes の実験式（(1)式鉛直面）を適 用した。鉄骨の表面温度は、天井近くの3 測定点の平均值を用い た。

(3)室の蓄熱への影徐

室内鉄骨のうち、柱、梁、気流測定用トラバース装置はポリスチ レンボードにより、北壁、床とは断熱されているため、サッシュの 熱容囯のみをガラス面（恵西南、屋根）の熱容舅に加算し、壁体の 蓄熱を評価した。柱、梁、トラバース装置の蓄熱の影䇺に関しては は本報では直接評価しない。その蓄熱の効果は、室内空気への対流 熱伝達により、室内空気温度の日射変動に対するタイムラグとして 現れる。計算に用いた各壁の熱容量を表 3 に示す。 

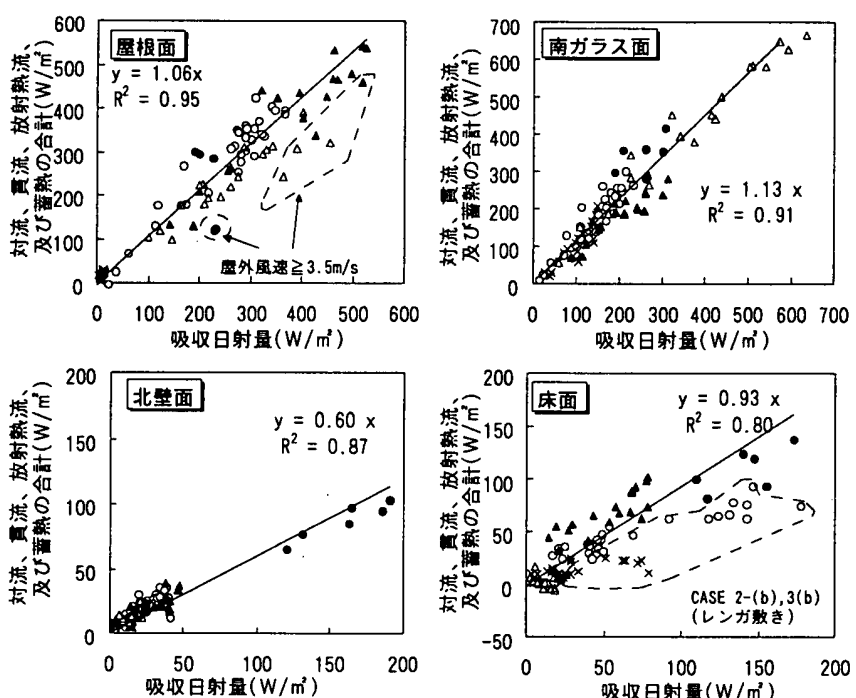

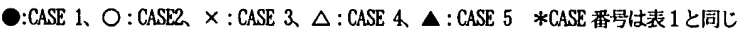
図2. 各室内壁面の熱収支(蓄熱、鉄骨の影響を考虑)

\section{3. 各室内壁面における熱収支}

室内各壁面（東西南、天井、北壁、林）の熱平衡は、室内表面 $\mathrm{i}$ への流入熱量を正とすると、次式で示される（簡便のため壁体内温 度は一様と仮定注 ${ }^{3}$ )。

$$
C_{w i} \cdot \frac{d T_{w i}}{d t}=I_{i}+J_{i}+\alpha_{c i} \cdot\left(T_{i n}-T_{s i}\right)+K_{i} \cdot\left(T_{\text {out }}-T_{s i}\right)
$$

但し、 $C_{w i}$ : 面 $i$ 単位面稙当たりの比鶖、 $T_{w i}$ ：壁体の温度、

$I_{i}$ : 吸收日射量、 $J_{i}$ : 室内長波放射取得 (入射量から放射量を差し引いたも の。)、 $\alpha_{c 1}$ : 室内側対流㷬云達保数、 $T_{1 n}$ : 室温、 $T_{s i}$ : 表面温度、

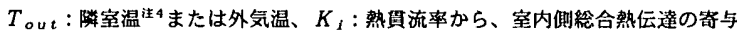
を除いたもの、添字 $i$ : 壁面番号

(3)式中、室内温熱環境形成の主要素である吸収日射量を左辺に 置き、他の項を右辺に置き、書き改めると(4)式のようになる。各 部位の温度変化が小さく、蓄熱項の影響も小さいと考えられる 13:00、14:00の測定値を選び、表 1 に示す全ての実験結果を(4)式 に当てはめ、収支を検討した注 5 、注 6 。

$$
I_{i}=\alpha_{c i} \cdot\left(T_{s i}-T_{i n}\right)+K_{i} \cdot\left(T_{s i}-T_{o u t}\right)-J_{i}+C_{w i} \cdot \frac{d T_{w i}}{d t}
$$

計算において、各壁体の蓄熱量は、壁体温度 $T_{w i}$ として表面温 度 $T_{s i}$ を用い、対象時間前後 15 分の温度変化量から求めた。

検討結果を図 2 に示す。横軸が(4)式左辺:吸収日射量、縦軸が(4) 式右辺: 対流、貫流、放射、蓄熱の寄与の和に対応している。図中に は、(4)式右辺を目的変数に、左辺を説明変数とし、定数項を 0 とし た回帰分析結果も併せて示した（屋根面の結果では、外気風速か $3.5 \mathrm{~m} / \mathrm{s}$ 以上の結果、林面の結果では床面にレンガを教きつめた CASE2,3-(b)の結果を除いて回州分析した)。

屋根面、南ガラス面については回帰係数は約 1.1 、寄与率は 0.9 以上あり、測定值の (4)式への適合度は概ね良い。屋根面に関する 結果では、外気風速が大きい実験ヶースで、(4)式右辺の過小評価 か認められる。これは屋外総合熱伝達係数の過小評価に起因するも のと思われる。北壁面、床面では日射吸収率の高い CASE1 の傾きが 小さく、(4)式左辺（横軸）の過大評価、もしくは右辺（縦軸）の 過小評価の傾向が観察される。また、床面ではレンガを教いた CASE2、3-(b)は特に適合度が悪い。

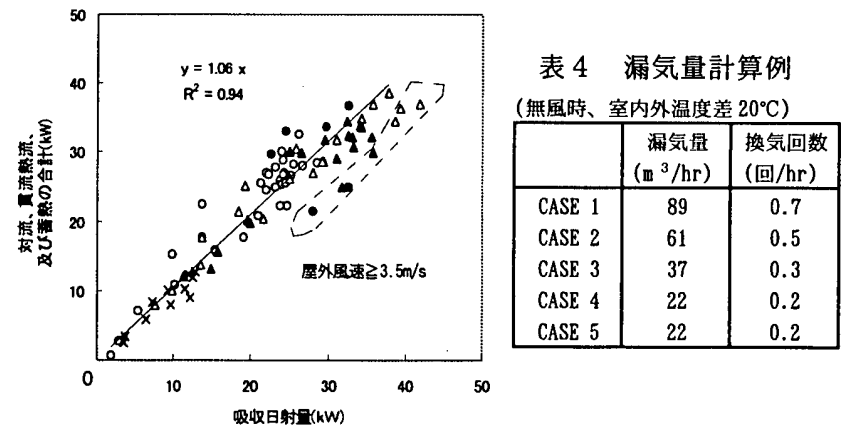

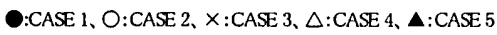

図3室全体の熱収支 $(13: 00 、 14: 00)$

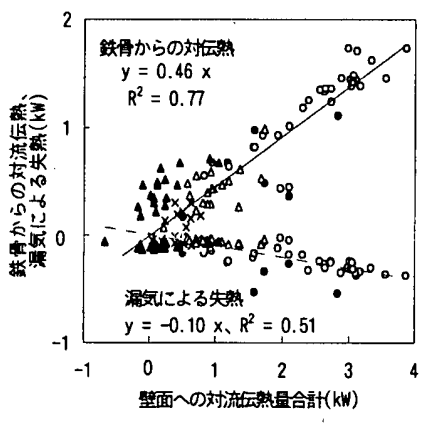

図4. 室内空気の熱収支に対する 鉄骨からの発熱、漏気の寄与

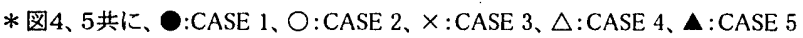
(CASE 番号は表1と同じ)

次に(5)式に示すように、(4)式を各面（東西南、屋根、北壁、床 の6面）について足し合わせ、室全体内表面の熱収支を検討した。

$$
\sum_{i} I_{i} \cdot S_{i}=\sum_{i} S_{i}\left\{\alpha_{c i} \cdot\left(T_{s i}-T_{i n}\right)+K_{i} \cdot\left(T_{s i}-T_{o u t}\right)+C_{w i} \cdot \frac{d T_{w i}}{d t}\right\} .
$$

図 3 に(5)式左辺（各面の日射吸収量の合計）を横軸に、右辺 （各面の対流、貫流、及び蓄熱の合計）を縦軸とした分析結果を示 す。図のように、外気風速が大きいときは(5)式右辺の過小評価の 傾向が認められるが、これらの測定データを除けば、回㷌係数は 1.06、寄与率は $0.94 、(5)$ 式左辺と右辺の二乗平均誤差(RMSE; Root Mean Square Error)は約 2800Wであり、快晴時では約 5\%程度 である。室全体では熱収支を概水満たす測定・解析結果となってい ることを確認した。

\section{4. 室内空気における熱収支}

室内空気の熱平衡は、室内空気への流入熱量を正とすると、次式 で示される。

$$
C_{a} V_{a} \frac{d T_{\text {in }}}{d t}=\sum_{i} \alpha_{c i} \cdot\left(T_{s i}-T_{\text {in }}\right) \cdot S_{i}+Q_{G}-Q_{L}
$$

但し、 $S_{i}$ : 各壁面の面積、 $C_{s}$ : 空気の熟容昌、 $V_{a}$ : アトリウムの体積、 $Q_{G}$ ： 暖屏による取得熱量、日射により加熟された室内鉄骨からの取得熱量なと、

$Q_{L}$ : 自然換気、漏気、冷房なとによる失㠇量

(6)式を空気から壁への対流伝熱量に対する他要素のバランス 式：(7)式に書き換え、表 1に示す全実験について、13:00、14:00 の測定値を当てはめ、室内空気の熱収支を検討した注 7 。

$$
\sum_{i} \alpha_{c i} \cdot\left(T_{i n}-T_{s i}\right) \cdot S_{i}=Q_{G}-Q_{L}-C_{a} V_{a} \frac{d T_{i n}}{d t}
$$

(7)式中、 $Q_{G} 、 Q_{L}$ として、それそれ、日射により高温となってい る室内鉄骨からの対流伝熱による取得熱量、及び漏気による失熱量

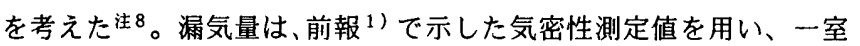


モテル回路網法 ${ }^{6)}$ により漏気量の見積もりを行った。この計算で は室を上下 5 分割し、隙間は各ブロック壁面の中心に集中して存在 すると仮定した。漏気失熱昷は「各ブロックにおける侵入空気量と 室内外温度差の橨の合計」と定義した。典型的な㴮気量の計算例 （無風時、室内外温度差 $20^{\circ} \mathrm{C}$ ）を表 4 に示す。室内鉄骨からの対流伝熱 による取得熱量の計算方法は前述した通りである。室内空気の蓄熱量 は、対象とする時間の前後 15 分の平均室温の変化盢から評価した。

図 4は、(7)式左辺 : 壁面への対流伝熱量合計と鉄骨からの伝熱 量、及ひ漏気失熱の関係を示したものである。図より、鉄骨からの 对流伝熱蛋と壁面への伝熱量合計值は冝的には一致しないものの、 かなり強い相関を持つことがわかる。これは、床面等の加熱面の面 貿と同等以上の表面稳を有する室内鉄骨か、室内空気加熱の主要因 であることを示唆する。個々の寒験ケースに着目すると、室内への 透過日射量が小さい CASE3、4、5（遮光屋根、または熱線反射ガラ スを利用）で、鉄骨からの対流伝熱量が小さくなっていることが確 認できる。一方、漏気失熱冝も壁面への伝熱冝合計値と有意な相関 を持っている（鉄骨の寄与:0.46/漏気の寄与:-0.1）。回帰係效を比較 すると、以上に示した計算条件下では漏気失熱量は鉄骨からの発熱 冝の約 $25 \%$ と評価される。

図 5 に、(7)式左辺：壁面への対流伝熱量合計を横朝に、右辺： 鉄骨からの伝熱量、漏気、蓄熱の寄与の合計を綎軸にした分析結果 を示す。また、(7)式右辺に関し、左辺を説明変数とした単回帰分

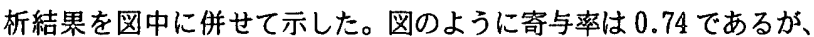
回帰係效は 0.36 と小さく、測定値の $(7)$ 式への適合度は良いとは言え ず、壁面への対流伝熱量の過大評価、もしくは鉄骨発熱、漏気失熱、 蓄熱の寄与の和の過小評価の傾向が表れた。特に気密性の悪い CASE1 は、その傾向が強い。但し、(7)式各項のオーダーは效 $\mathrm{k}$ 程度であ り、ガラス・壁面での吸收日射量・貫流熱量と比較すると、かなり小 さな値であり、室全体の熱収支への影響は小さいと思われる（図 3、 図 1 1参照)。

以上のように、一般的な熱伝達係数を適用することで、測定值は熱
收支をほほ満足し、実測の妥当性を確認した。また、本研究で得られ た測定結累は種々の明確な境界条件、すなわち天候、抙節、アトリウ 么環境の設計上重要な代表的因子を系統的に包含しており、数值解析 手法の検証用データとして有効と思われる。

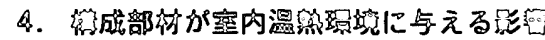

アトリウム環境設計において重要となる各種のアトリム構成部材 が自然室温時の室内熱環境、熱翰送特性に与える影響を解析する。

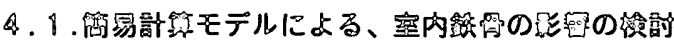
前節では、室内の熱収支に関与する種々の影畋因子について铪討し、 日射により熱せられた室内鉄骨からの対流伝熱か、室内空気加熱の主要 索であることを示した。ここでは表 1に示す全ての実験（13:00、14:00の 測定值)に関し、戸河里らのブロックモデルを適用し7)、注9、日射、 外気温、䑝室温度測定値より、室内空気温度 - 内壁表面温度の分布 の計算を行い、実測結果と比較した。解析にあたり、(a) 銑骨から の対流伝熱の影響、及び(b) 鉄骨、サッシの日射取得への影響を検 討した。考え方は 3 章と同㥞である。この 2 種の因子を考應した計 算結果を図 6 に示す。計算値を目的変数、測定值を説明変数とした 単回經分析の結果、及び測定値と計算値の二重平均誤差 (以下 RMSE)を図中に示す（北壁面では、CASE2-(b)、3-(b)を除いて回帰 分析を行った）。図中（）内の数字は 銑骨からの対流伝熱を無視 した場合の RMSE である。

回㷌分析により得られた回帰係数は 0.97 から 1.03、寄与率は 0.90 以上であり、上記の 2 因子を考虑することで、室内温度分布 が概ね正確に予測可能となることが検証された。鉄骨表面稳の約 7 割が存在する上段ブロックの空気温度では、鉄骨からの対流伝熱を 無視した場合の RMSE は $5.1^{\circ} \mathrm{C}$ と大り值をとるが、それを考應す ることて RMSE は $2^{\circ} \mathrm{C}$ と最も小さくなる。上段フロックでは鉄骨か らの対流伝熱の影留が特に強く現れているものと考えられる。床表 面温度では、レンガを敨き詰めた場合（CASE2-(b)、3-(b)) の温度 推算精度が悪く、蓄熱効果を考舁する必要があると思われる。
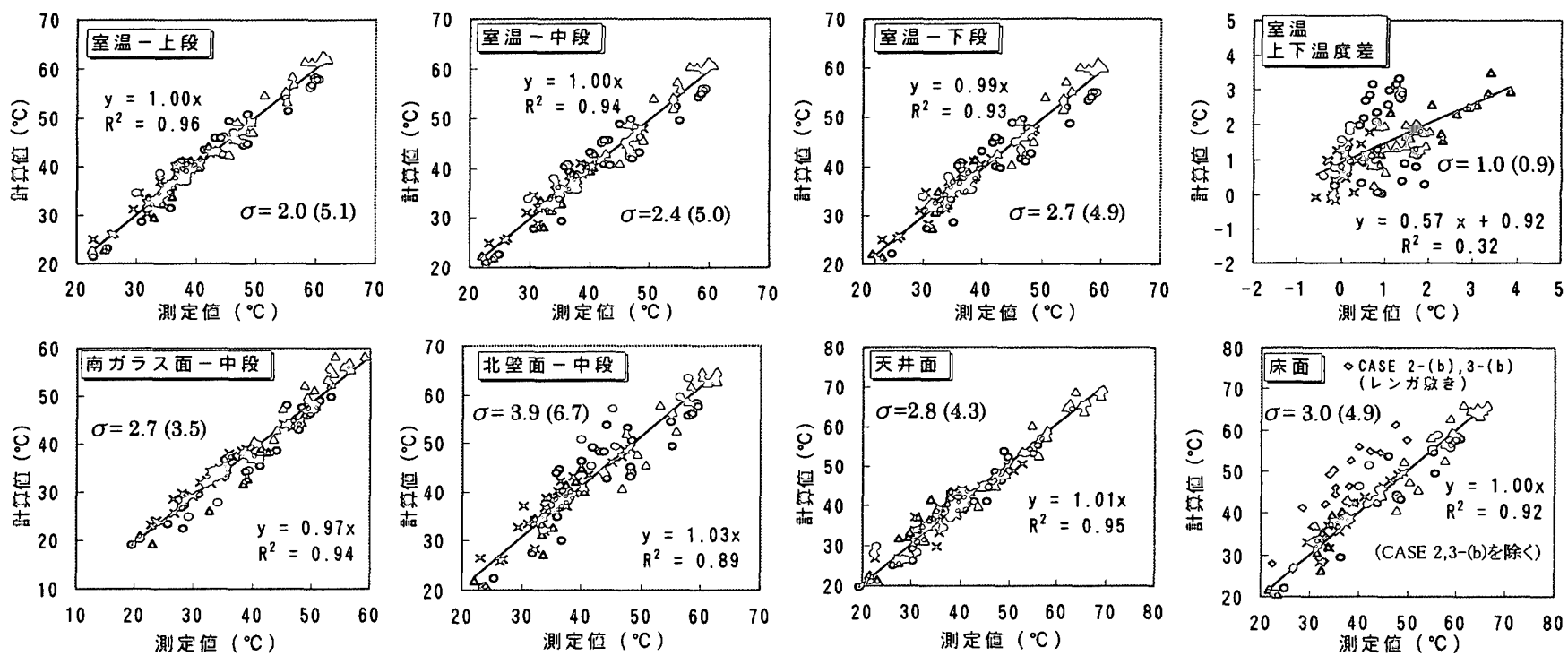

O:CASE $1 、 O: \operatorname{CASE} 2 、 \times: \operatorname{CASE} 3 、 \triangle: \operatorname{CASE} 4 、 \triangle: \operatorname{CASE} 5$ (CASE 番号は表1と同し)

図6 簡易モデルによる温度計算結果（鉄骨からの対流伝熱、鉄骨の日射遮蔽を考息。13:00、14:00 の結果。）

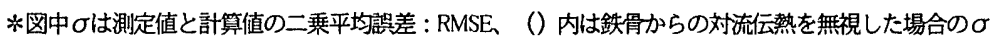




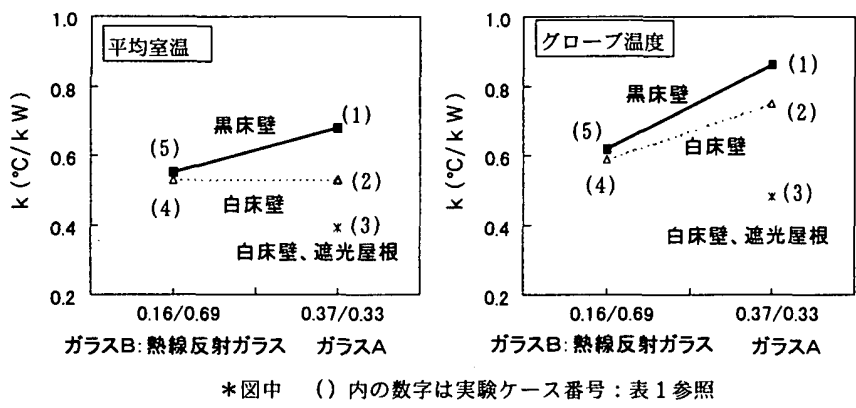

図 8 構成部材と平均室温、グローブ温度の関係

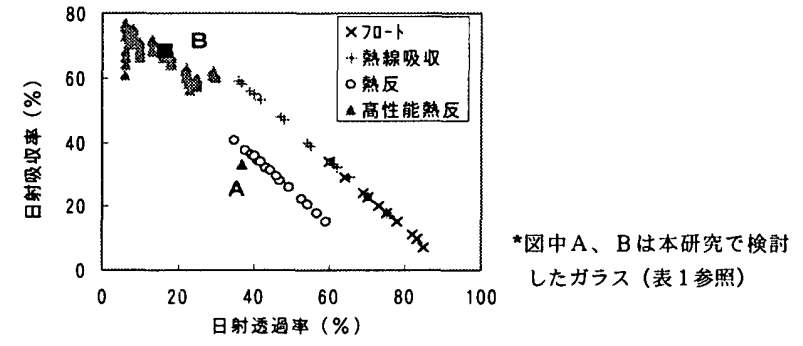

図 9 一般建築用ガラス (単板) の光学特性

表 4-1 気象条件（'95 4/22 13:00）表 4-2 北壁、床の光学特性

\section{外気温 : $23^{\circ} \mathrm{C}$}

水平面全天日射量 : $850 \mathrm{~W} / \mathrm{m}^{2}$ 、

水平面天空日射量 : $175 \mathrm{~W} / \mathrm{m}^{2}$

隣空温度 : $23^{\circ} \mathrm{C}$ 、床下温度 $: 22^{\circ} \mathrm{C}$

表 $4-3$ ガラスの光学特性 ${ }^{8)}$

\begin{tabular}{|c|c|c|c|c|}
\hline 品種（品種数） & 日射透過率 & $\begin{array}{c}\text { 日射吸収率 } \\
\text { (屋外側) }\end{array}$ & $\begin{array}{c}\text { 放射率 } \\
\text { (室内側) }\end{array}$ & $\begin{array}{c}\text { 日射熱 } \\
\text { 取得率 }\end{array}$ \\
\hline フロート (1 種) & 0.69 & 0.24 & 0.84 & 0.78 \\
熱線及収 $(3)$ & $0.39 \sim 0.42$ & $0.53 \sim 0.59$ & 0.84 & $0.57 \sim 0.60$ \\
熱線反射 (4) & $0.39 \sim 0.55$ & $0.22 \sim 0.40$ & 0.84 & $0.43 \sim 0.60$ \\
高性能熱線反射 (13) & $0.06 \sim 0.30$ & $0.61 \sim 0.77$ & $0.31 \sim 0.67$ & $0.30 \sim 0.49$ \\
\hline
\end{tabular}

“計算においては、窒内例の入射光に対する日射吸收率も考虑した。

以上より、室内鉄骨からの対流伝熱が、室内温度分布に大きな影复 を与えることは明らかである。本報告では室内鉄骨温度を末知数と する温度計算を行っていないが、アトリウムの温熱環境設計には、 室内鉄骨のように日射により局所的に加熱された部位からの対流伝 熱量の正確な見積もりが必要と考えられる。

\section{2.ガラス・壁の光学物性の影霓}

前報で示したように、アトリウム温熱環境はガラス、室内壁の双 方の光学特性の影響を受ける。前報の測定結果を図 8 に整理した。 図中、縦軸 $\mathrm{k}$ 值 ${ }^{1)}$ は東西南、屋根の 4 面に入射する全日射量に対 する外気温基準の温度上昇率である。横軸は使用ガラスの日射透過 率／日射吸収率を示している。壁床の色が黒色の場合は、日射透過 率の低いガラスBを用いることで、室温・グローブ温度ともに低下 することが認められる。一方、壁床の色が白色の場合は、日射透過率 の低いガラスBを用いることでグローブ温度は低下するが、室温は低 下しない。室内温熱環境はガラス、内壁体双方の光学物性の影響を受 けることか明らかである。

本節では、構成部材の光学特性とアトリウム温熱環境の関係を更 に詳しく検討するために、当実験用アトリウムを対象としたケース スタディを行った。東西南、屋根を厚さ $12 \mathrm{~mm}$ の単板ガラスと し、他の構成は表 1 と同様とした。検討条件を表 4 に示す。表 4 中 の北壁・床品種 3 種、ガラス品種 21 の組み合わせ $(3 \times 21 ：$ 計 63
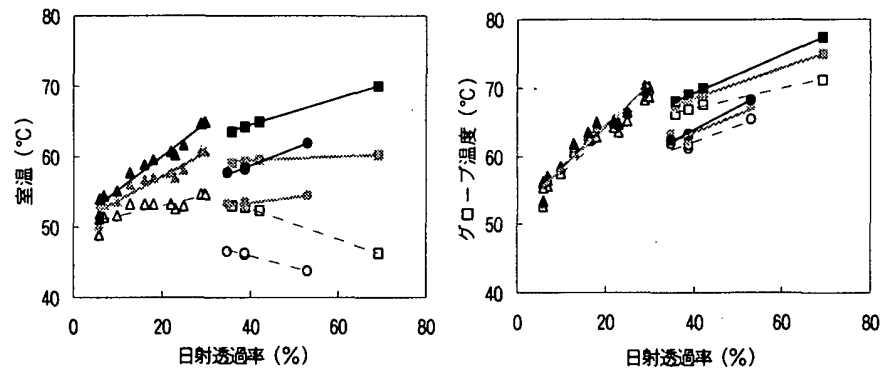

(1)日射透過率と室温、グローフ温度
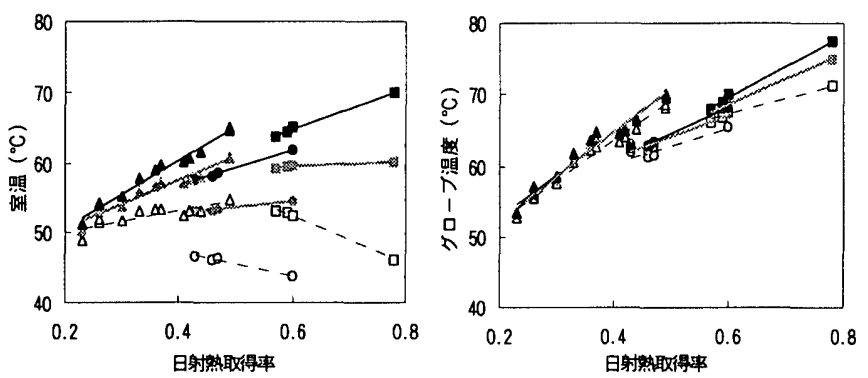

(2)日射熱取得率と室温、グローフ温度

\begin{tabular}{|c|c|c|c|}
\hline \multirow[b]{2}{*}{ ガラス品種 } & \multicolumn{3}{|c|}{ 北瑟·床の日射吸収率 } \\
\hline & 0.2 & 0.6 & 1.0 \\
\hline フロート、熟線吸収 & $\square$ & 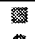 & 口 \\
\hline 熟線反射 & 0 & 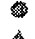 & 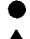 \\
\hline
\end{tabular}

図 10 一般建築用ガラスを対象としたケーススタディの結果

種）に関して、簡易計算モデル（前節参照）を用い、室内平均温

度、及びグローブ温度注10（室中央、高さ $1 \mathrm{~m}$ ）を求めた。

参考までに図 9 に一般建築ガラス (単板) の光学特性を示す。図 のように、光学特性により建築用ガラス (単板) は 3 種のグルー フ、1)フロートガラス・熱線吸収ガラス、2)熱線反射ガラス、3)高 性能熱線反射ガラスに分類可能である。

検討結果を図 10 に示す。室温とグローブ温度について、ガラス 特性（日射透過率、日射熱取得率）との関係としてまとめた。

(1) 上述の光学特性の異なる 3 種のガラス間で、室温、グローブ温

度共に傾向が異なることが認められた。

(2) 室温はガラスの日射透過率・日射熱取得率たけで決まらず、室 内壁の光学特性の影響を強く受ける。また、ガラスの日射熱取 得率、日射透過率が大きくなるほど、室内壁の光学特性による 室温の差異は大きくなる。一般建築と比較して、当アトリウム ではガラス面積が大きいため、室内の相互反射の影響、室内か ら屋外への再放射（ガラスを通じる）の影響が強く現れたもの と考えられる。

(3) グローブ温度はガラス種別により多少の差異はあるが、日射熱 取得率との相関は強く、室内壁の光学特性にはほとんど依存し ない。これはグローブ温度は室内への透過日射光（特に直達 光）の影響を強く受けるためと思われる。カララス面積が大きい 空間では日射熱取得率は体感温度の判定に適したパラメータと 思われる。

\section{3. 各壁面における熱授受特性と温熱環境}

3 章で得られた解析結果をもとに、構成部材による各壁面の熱授 受特性の違いを明らかにし、構成部材が室内温度性状に与える影響 を考察する。同様の解析を C F D、放射連成で解析する際、本結果 は特に重要な検証項目となる。表 5 は快晴時の 13:00における全入 
射日射冝に対する、各面の対流、貫流、長波放射 伝熱輏を示したものである。ここでは、簡略化の ためにアトリウムを椿成する 6 面を“屋根・南ガラ ス“、”北壁・底“、”東西ガラス“の3グループに分 けまとめた。図 11 は全ての実験 CASEについ て、各面それそれの全入射日射量に対する貫流、 長波放射、対流による伝熱量の分配状況をまとめ たものである。図中 $\mathrm{k}$ 值 ${ }^{1)}$ は各壁面の温度上昇率 （全入射日射量に対する外気温基準の温度上昇 率 : $\left.10^{-4 \circ} \mathrm{C} / \mathrm{W}\right)$ である。

表 5 に示されるように、各壁面、室全体（各壁 面の寄与の和）における収支分析の残差は、全入 射日射冝に対し $\pm 10 \%$ 以内である。

図 11 に示す室内の熱授受に着目すると、いずれ の CASE についても、吸収日射量の大部分が、ガラ ス面からの貫流熱で室外に放熱されている。しかし 下記のように、檴成部材の種類により、各伝達熱冝 の配分、熱流の方向は異なり、室内温度性状もそれ に応じ異なったものになっている。 (1) CASE 1 は黒色の北壁・床面に吸収日射量が多 く分配され、ガラス面が冷却面として働くた め、他の条件と比較して長波放射による熱の授 受が活発である。また、CASE 2,5でも量が小さ いか、北壁・床面から他壁面に向かう長波放射 熱伝達が認められる。逆に、CASE4 の屋根・南カ ラス面は吸収日射量が多く配分され、白色の北 壁・床面より高温となるため、屋根・南ガラス 面から他壁面に向かう長波放射熱伝垟が認めら れる。

(2) CASE1 とCASE2 を比較すると、屋根、南面の吸収日射是は同等で あるか、CASE1 では高温壁である北壁面からの長波放射伝熱、室空 気からの対流伝熱を更に受けるため、屋根、南面の温度上昇率は CASE2 より高くなる。

(3) CASE4、5 の総吸収日射量はほぼ等しいが、CASE4 は CASE5 に比較して ガラス面の吸収日射量は多く、北壁面の吸収日射䝮は少なく配分されて いる。その結果、CASE4 では屋根・南ガラス面温度>室温〉北壁・床面 温度、CASE5 では屋根・南ガラス面温度く室温<北壁・床面温度となっ ている。また放射伝熱、対流伝熱の向きもそれに対応して、CASE4では 屋根・南ガラス面から北壁・床に向い、CASE5 では逆に北壁・床から屋 根・南ガラス面に向っている。

(4) 北壁・床面から室内空気への対流伝熱量は、北壁・床面の吸収 日射昷の小さいCASE2,4では小さく、吸収日射量の大きい CASE1,5 では大きい。その結果、前者では北壁・床面温度と室温 の差は小さく、後者では北壁・床面温度が室温と比較してかなり 大きな值をとる。

(5) 室内鉄骨からの対流伝熱か室内空気加熱の主要索となっている ことは既に示したが、遮光屋根を設けたCASE3、日射透過率の低 いガラスを用いたCASE4,5では、鉄骨への入射光が低減されるた めに、鉄骨からの対流伝熱が CASE1,2 と比較して小さいことが認 められる。
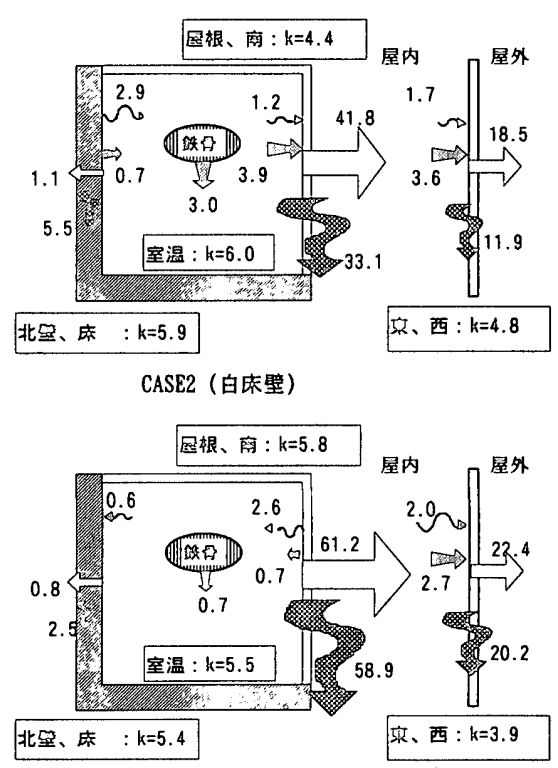

CASE4（白床壁、熱線反射ガラス）

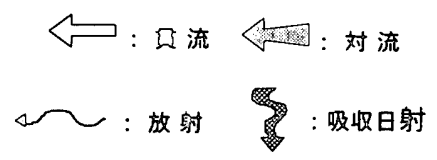

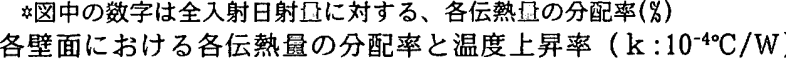

表 5 各壁面における各伝熱量の分配率（\%)

*流入を正、流出を負とする。全入射日射量を $100 \%$ としている。

\begin{tabular}{|c|c|c|c|c|c|c|c|}
\hline & & 吸收日射五 & 貫流 & 対流伝熱 & 長波放射 & 蓄熱 & 残美 \\
\hline $\begin{array}{ll}\mathrm{CASE} & 1 \\
94 & 2 / 18\end{array}$ & $\begin{array}{c}\text { 屋根、南 } \\
\text { 東、西 } \\
\text { 北壁・床 } \\
\text { 合計 } \\
\text { (鉄骨) }\end{array}$ & $\begin{array}{r}32.6 \\
8.8 \\
20.6 \\
62.0\end{array}$ & $\begin{array}{r}-51.5 \\
-21.1 \\
-1.4 \\
-74.0\end{array}$ & $\begin{array}{r}5.1 \\
5.5 \\
-6.2 \\
4.4 \\
-2.1 \\
\end{array}$ & $\begin{array}{r}3.1 \\
3.3 \\
-6.4 \\
0.0\end{array}$ & $\begin{array}{c}0.3 \\
-1.4 \\
0.5 \\
0.6\end{array}$ & $\begin{array}{c}-10.4 \\
-4.8 \\
7.0 \\
-8.2\end{array}$ \\
\hline \begin{tabular}{|l|} 
CASE 2 \\
$948 / 27$
\end{tabular} & $\begin{array}{c}\text { 屋根、南 } \\
\text { 東、西 } \\
\text { 北壁・淕 } \\
\text { 合計 } \\
\text { (鉄骨) }\end{array}$ & $\begin{array}{r}33.1 \\
11.9 \\
5.5 \\
50.5\end{array}$ & $\begin{array}{r}-41.8 \\
-18.5 \\
-1.1 \\
-61.4\end{array}$ & $\begin{array}{c}3.9 \\
3.6 \\
-0.7 \\
6.8 \\
-3.0\end{array}$ & $\begin{array}{r}1.2 \\
1.7 \\
-2.9 \\
0.0\end{array}$ & $\begin{array}{l}-0.2 \\
-1.6 \\
-0.2 \\
-2.1\end{array}$ & $\begin{array}{r}-3.9 \\
-2.8 \\
0.6 \\
-6.1\end{array}$ \\
\hline $\begin{array}{c}\text { CASE } 3 \\
94 \quad 5 / 22\end{array}$ & $\begin{array}{c}\text { 屋根、南 } \\
\text { 東、西 } \\
\text { 北壁·床 } \\
\text { 合計 } \\
\text { (鉄骨) }\end{array}$ & $\begin{array}{r}8.9 \\
11.5 \\
2.5 \\
22.8\end{array}$ & $\begin{array}{l}-10.0 \\
-12.0 \\
-0.5 \\
-22.5\end{array}$ & $\begin{array}{c}0.2 \\
0.5 \\
0.2 \\
0.8 \\
-0.1 \\
\end{array}$ & $\begin{array}{c}-0.1 \\
0.1 \\
0.0 \\
0.0\end{array}$ & $\begin{array}{l}-0.9 \\
-1.4 \\
-0.5 \\
-2.7\end{array}$ & $\begin{array}{r}-2.0 \\
-1.3 \\
1.7 \\
-1.6\end{array}$ \\
\hline $\begin{array}{c}\text { CASE } 4 \\
, 95 \quad 1 / 25\end{array}$ & $\begin{array}{c}\text { 屋根、南 } \\
\text { 查、西 } \\
\text { 北壁·床 } \\
\text { 合計 } \\
\text { (鉄骨) }\end{array}$ & $\begin{array}{c}58.9 \\
20.2 \\
2.5 \\
81.6\end{array}$ & $\begin{array}{r}-61.2 \\
-22.4 \\
-0.8 \\
-84.4\end{array}$ & $\begin{array}{r}-0.7 \\
2.7 \\
0.0 \\
2.0 \\
-0.7\end{array}$ & $\begin{array}{r}-2.6 \\
2.0 \\
-0.6 \\
0.0\end{array}$ & $\begin{array}{c}1.9 \\
-3.0 \\
-0.2 \\
-1.3\end{array}$ & $\begin{array}{c}-3.7 \\
-0.5 \\
0.9 \\
-3.3\end{array}$ \\
\hline $\begin{array}{l}\text { CASE } 5 \\
958 / 10\end{array}$ & $\begin{array}{c}\text { 屋根、南 } \\
\text { 東、西 } \\
\text { 北壁·床 } \\
\text { 合計 } \\
\text { (鉄骨) }\end{array}$ & $\begin{array}{r}51.5 \\
19.1 \\
8.4 \\
82.0\end{array}$ & $\begin{array}{r}-56.4 \\
-23.0 \\
-1.5 \\
-80.9\end{array}$ & $\begin{array}{c}1.0 \\
3.0 \\
-3.6 \\
0.4 \\
-1.1 \\
\end{array}$ & $\begin{array}{r}0.2 \\
3.7 \\
-3.9 \\
0.0\end{array}$ & $\begin{array}{c}3.1 \\
-2.6 \\
0.2 \\
0.7\end{array}$ & $\begin{array}{r}2.3 \\
0.3 \\
-0.3 \\
2.2\end{array}$ \\
\hline
\end{tabular}

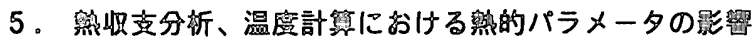

図 12 に示すように、静穏空気中に置かれた発熱面、冷却面での 自然対流に伴う対流熱伝達係数の実験式はいくつか提案されている か55)，9）、それそれ大きく異なる值をとる。3、4 章で用いた 
Wilekes $の$ 実験式は比較的大板 $(80 \mathrm{~cm} \times 240 \mathrm{~cm})$ の実験によるもの で、室内実験模型 $(3 \mathrm{~m} \times 3 \mathrm{~m} \times 3 \mathrm{~m})$ を用いた小林の值と比較的近い値を とり、これらの值は垂直面、水平面上昇流では他より大きめである （垂直面に関しては図を省略）。

ここでは、表 6 に示すように、室内側対流熱伝達係数、屋外総 合熱伝達係数を変化させて、熱収支分析、温度計算を行い、その 影響を検討した。表中 CASE C が本報告 3、4 章で使用した熱伝 達係数の組み合わせである。図 13 に $3 、 4$ 章同様、回帰分析に より求めた回帰係数、寄与率を示す。図 $13-(1)$ は(4)式、また は(7)式の右辺を目的変数に、左辺を説明変数とし、回帰分析した 結果、図 $13-(2)$ は温度計算值を目的変数、温度測定值を説明変 数とし、回帰分析した結果である。

図中 A、B、C、D は屋外総合熱伝達係数を $17.4 \mathrm{~W} / \mathrm{m}^{2} \cdot \mathrm{K}$ に固定 し、室内対流熱伝達係数を変化させた結果である。E、C、F は室 内対流熱伝達係数にWilekes $の$ 実験式を適用し、屋外総合熱伝達 係数を $11 \sim 23 \mathrm{~W} / \mathrm{m}^{2} \cdot \mathrm{K}$ の範囲で変化させた結果である。

(1)室内側対流熱伝達係数 $\left(\alpha_{c}\right)$ の影響 (CASE A, B,C,D)

ガラス面の熱収支では吸収日射量と外側への貫流熱が支配的で あるため、熱収支の適合度においても、温度推算精度において も、 $\alpha_{c}$ の影響は小さく、回帰係数、寄与率の動きは小さい。一 方、北壁面、休面では $\alpha_{\mathrm{c}}$ が大きいほど、熱収支の適合度、温度 推算精度ともに向上する。室内空気については、熱収支の適合度 は $\alpha_{\mathrm{c}}$ により大きく変化するが、温度推算精度の変化は小さいの が特幑的である。Wilkes の実験式を用いたCASE Cでは、室内空 気に対する熱収支の適合度は悪いが、その原因は不明である。加 熱面、冷却面の $\alpha_{c}$ の大小関係が、熱収支式への適合度に強く影響 しているものと考えられる。本研究の検討範囲 CASE A〜Dでは、 $\alpha_{\mathrm{c}}$ の最も大きいCASE D (7W/ m $\left.{ }^{2} \cdot \mathrm{K}\right)$ を用いたとき、熱収支分 析、及び温度計算ともに、最も良好な結果が得られている。

(2)屋外総合熱伝達係数 ( $\alpha_{\circ \mathrm{out}}$ ) の影響（CASE E,C,F）

熱収支に関しては、ガラス面では $\alpha_{\text {ou t }}$ の影響を強く受け、断 熱壁である北壁面、休面ではその影響は非常に小さい。一方、温 度推算精度では、全ての部位で、 $\alpha_{\text {out }}$ の影響が強く現れ、この 值が大きくなるほど、回帰係数は小さく(計算温度) は小さくな る。熱収支の適合度、温度推算精度における回帰分析結果を見る と、3、4 章で用いた $\alpha_{\mathrm{out}}$ の值 $\left(17.4 \mathrm{~W} / \mathrm{m}^{2} \cdot \mathrm{K}:\right.$ CASE C) は妥 当であったと考えられる。

\section{6. 結論}

長期にわたる実験用アトリウム室内の温熱環境の実測結果に関 し、自然室温状態における室内熱収支、熱輸送性状をアトリウム構 成要素の観点から統計的に解析した。測定結果は室内熱収支を充分 説明し、C F D（数值流体力学）・放射連成解析を代表とする数值 解析手法の検証用データと成り得る。またアトリウム室内の環境分 析で重要となる各種構成要素が室内環境に与える影響を定量的に検 討した。統計的解析の主要な結果は以下の 4 点である。

(1)熱収支分析、簡易モデルによる室内温度分布計算の結果、日射 により加熱された鉄骨からの対流熱伝達が室内空気加熱の主要素 であることが明らかになった。アトリウムの温熱環境設計には、 室内鉄骨のように日射により局所的に加熱された部位からの対流
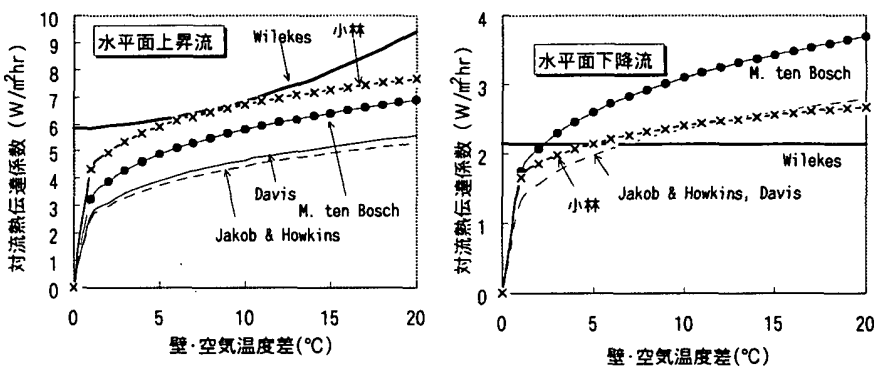

図 12 自然対流時における室内側対流熱伝達係数の実験式

表6 感度分析に用いた熱伝達係数の組み合わせ (単位 $\left.\mathrm{W} / \mathrm{m}^{2} \cdot \mathrm{K}\right)$

\begin{tabular}{|c|c|c|c|c|c|c|}
\hline case & $\bar{A}$ & B & C & D & $E$ & $F$ \\
\hline 鉛直面 & 2.3 & 3.0 & 3.7 & 7.0 & 3.7 & 3.7 \\
\hline 水平(上) & 2.3 & 4.0 & 6.2 & 7.0 & 6.2 & 6.2 \\
\hline 水平(下) & 2.3 & 1.0 & 2.2 & 7.0 & 2.2 & 2.2 \\
\hline 鉄骨の $\alpha \mathrm{c}$ & 2.3 & 3.0 & 3.9 & 7.0 & 3.9 & 3.9 \\
\hline 屋外総合熱伝達保数 & \multicolumn{4}{|c|}{17.4} & 11.6 & 23.3 \\
\hline
\end{tabular}

*表中、CASE C:Wilekes の実験值(鉄骨の $\alpha$ は鈆直面の式を適用)、CASE B: 建築設計资料集成に 記戟されている推奖値。CASE Cの值は表1の全実戨に適用したときの平均值である。
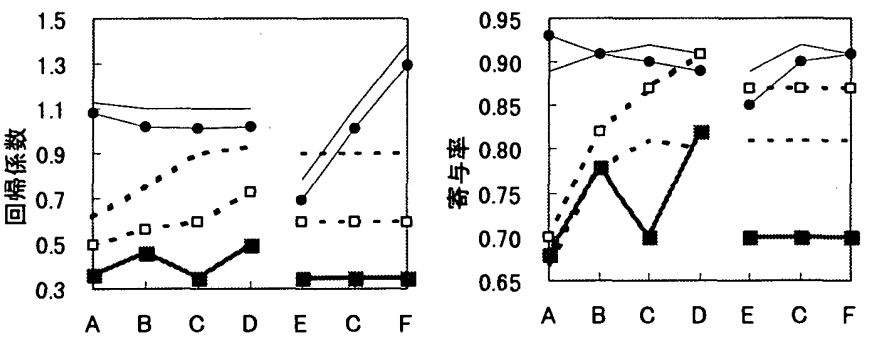

（1）熱収支の検討
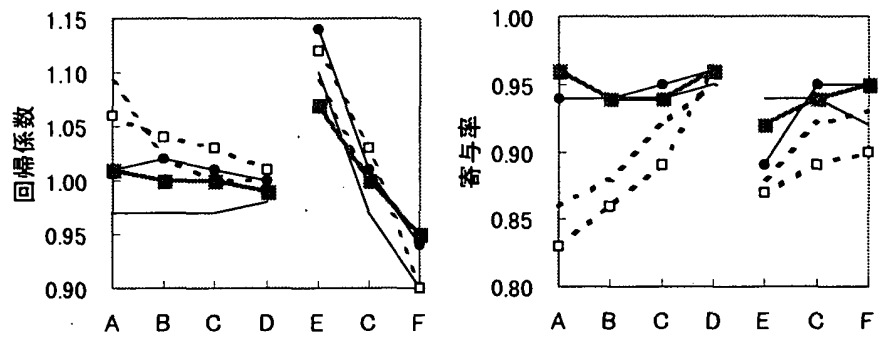

(2) 温度推算精度の検討

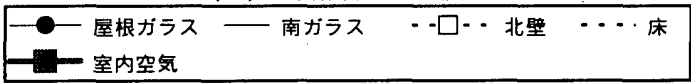

図 13 熱収支分析、温度計算ににおける熱的バラメータの影㸷

*図中横軸 $A \sim F$ は表 6 と同し

伝熱量の正確な見積もりが必要と考えられる。また、遮光部材、 低日射透過率ガラスなどの利用で、室内への透過日射量が小さい 場合は、鉄骨からの対流伝熱の影響も小さくなる。

(2)アトリウムのようにガラス面積が大きい空間では、室内の相互 反射の影響、室内から屋外への再放射（ガラスを通しる）の温熱 環境への影翼が強く現れる。そのため、室温はガラスの日射透過 率・日射熱取得率だけで決まらず、室内壁の光学特性の影響を強 く受ける。一方、グローブ温度は室内への透過日射光（特に直達 光）の影響を強く受けるため、日射熱取得率との相関は強く、室 内壁の光学特性にはほとんど依存しない。

(3)構成部材の種類、配置により、各伝達熱量の配分、熱流の向き は大きく異なったものになり、室内の温熱環境も異なったものと なる。自然室温時のアトリウム温熱環境の制御は、個々の部材だ けでなく、室全体としての伝達熱量の配分、熱流の向きを考慮す る必要がある。 
(4) 室内側詨流熱伝達係数は室内空気の熱収支分析結果へ大きく影

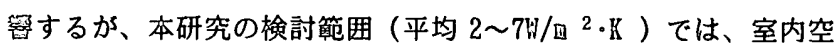
気温度の計算結界への影響は小さい。この検討䉇囲では、平均 7 W/四 $2 \cdot \mathrm{k}$ を用いたとき、熱収支、温度計算ともに良好な結果が得 られた。一方、屋外総合熱伝達係数はガラス面の熱收支に大きく 影響し、断熱壁、室内空気の熱収支に対する影響は小さいか、温 度計算結果に対しては全ての部位について強く影解する。本研究

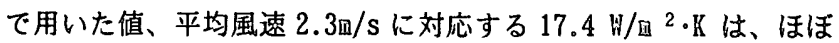
妥当なものと考えられる。

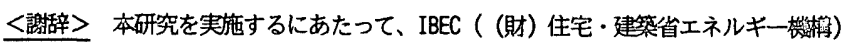

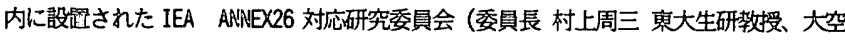
間における省エネルキ一換気研究）に参加寸る委員各位より、多くの有益なこ助言、 こ指垽を頂いた。ここに記して、感㴬の意を表明する。

\section{〈参考文献〉}

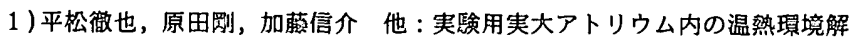

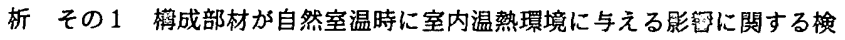
討，日本建築学会計画系論文報告集，№. 498，pp.37 44,1997.8

2) Yoshiich Ozeki, Shinsuke Kato, Shuzo Murakami: CFD Analysis on Flow and Temperature Fields in Experimental Real Scale Atrium, Vol. 3, $5^{\text {th }}$ International Conference on Air Distribution in Rooms, pp. $179 \sim$ $186,1996.7$

3 ) 平松徽也、原田剧，他 : 実䟻用実大アトリウム内の温熱懪境の解斩 その

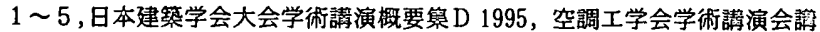
演論文篹 1995 1996

4 ) Tetsuya Hiramatsu, Takeshi Harada, Shinsuke Kato, et. al. :Study on Thermal Environment in Experimental Real Scale Atrium, Vol. 1, $5^{\text {th }}$ International Conference on Air Distribution in Rooms, pp. 523 $530,1996.7$.

5 ) 渡辺要編、建筑計画原論、丸善梌式会社(1965)、真京

6 ) 吉野骔，長友宗重，松本博，他：木造戸建住宅を対象とした自然換気卫の

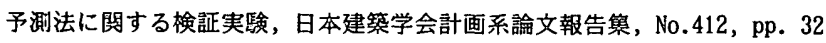
$\sim 41,1990.6$.

7 ) 戸河里敏, 荒井良延, 三浦克弘 : 大空間における上下温度分布の予测モテ ル（大空間の空調・熟瓄境計画手法の研究 その 1 ），日本建築学会計画系 論文報告鼠， No. 427 ,pp. 9 19，1991.9

8 ) 旭硝子板硝子建材総合カタロク

9 ) 小林定教：建筑物の室内側熱伝達特性に関する実験的研究 第 2 報 換気 のない室内における各面の流出入热口とその熱伝達特性について，日本建篡 学会論文報告篹, No. 292, pp. $78 \sim 86,1980.6$

$10)$ 片山忠久，塩月義隆，増田正一：放射環境下における気温およびグローフ 温度の測定精度に関する実験的研究，日本建築学会計画系論文算，№. 381 , pp. 20 26, 1987.11

<注〉

1 ) 室を上中下 3 ブロックに分割し、各フロックの壁面の吸収日射五を幾何学 的に求めた。相互拡散反射の寄与はあらかしめ各面間の形態係数を与えてお き、カウス・ザウテル法により計算した。

2 ) 長波放射授受は相互拡散反射口同様、ガウス・ザウテル法により算出。 3 ) (3)式はかなり大雑把な式であるか、温度変化が小さい13:00、14:00 の湖 定テータを用いた分析を行っていること、壁体の厚さは薄く板内の温度分布 は小さいこと（北壁・床面は断熱施工されているため、表㕣の合板のみを考 えた）を考えると、第 1 近似として、このような収支式を検討する価値があ ると思われる。

4) 落空温度は床、北壁に対し、それそれ床下温度、北側室の温度を用いた

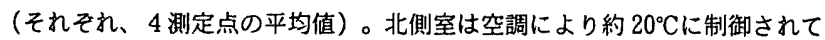
いる。床下は高さ $1.8 \mathrm{~m}$ の空間で、地面付近の 4 周囲加約 $20 \mathrm{~cm}$ 空いており、 常に換気された状態になっている。

5 ) 室を上中下 3 フロックに分け収支を検討した。図2 は上中下ブッッの平 均值を示している。フロックの空気温度は基本的にフロック平均温度を用い
たか、床面、天井面の参照温度とする場合のみ、面から $20 \mathrm{~cm}$ の位置の測定温度を 適用した。各フロックでの内壁表面温度は测定値の平均値を用いた。

6 )こうした検討の場合問題となるのが、各パラメータの綪度である。温度測定

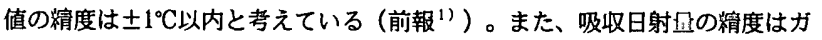
ラス面に対しては $10 \%$ 以内の精度であるが、北壁・床に関しては、計算手法に 問題を残し、約 $30 \%$ 過大評価されている(前報") 精度の検証を行っていない。Kについては、屋外側総合熱伝達係数が問題にな るが、これについては本文中 5 章で議論した。壁体の熱容冝については、1つ のモデル化手法の検証と考えて、鉄骨の就容亚も加算した值を用いた。放射計 算に関しては鉄骨の影琶は無視しており、今後の課題と思われる。

7 ) 室内空気の熱収支は、各壁面の熱収支分析同楟、室を上中下 3 フロックに 分け評価した。フロックの空気温度の考え方は注 4 ) と同様である。

$8) Q_{\mathrm{L}}$ の䋨度については、自然換気時の換気且の㨽定值を用い倹証してい る。（文献 3 ））。㨽定值、計算值は良い相関を有するか、計算値は測定値 を約 2 割過剩俨価する結果となっている。また $Q_{\mathrm{G}}$ に関しては、鉄骨表面温 度は直達日射が当たらない部分の測定值を用いてるため ( 3 測定値は約 $\pm 1{ }^{\circ} \mathrm{C}$ 以内に納まる)、多少小さな值をとっている可能性がある。

9 ) 熟収支計算と同槏に上中下 3 フロロックに分割し、各フロックの表面温度、 空気温度を計算した。但し、蓄熱の効果を無視した定常計算である。熱移動 係数 C B 值は $2 \mathrm{kcal} / \mathrm{hr}$ を操用した。

10 )グローフ温度は下記の熱収支式 ${ }^{10}$ ) より求めた（付図 1 参照）。参考ま でに当実唋アトリウムにおける測定値と計算値の比較を付図 2 に示す。各壁 面温度、室温は別途計算を実施した。

$\mathrm{a} \cdot \mathrm{I} \operatorname{dir} / 4+\sum \phi \mathrm{i}\left(\mathrm{a} \cdot \mathrm{I} \mathrm{dif}_{-} \mathrm{i}+\varepsilon \cdot \mathrm{IL} \mathrm{L}_{-} \mathrm{i}\right)-\mathrm{Jg}=\alpha \mathrm{g}(\mathrm{T} \mathrm{g}-\mathrm{T}$ in $)$

$(\mathrm{T} \mathbf{g}:$ グローブ温度、 $\mathrm{T}$ in: 室温

$\mathrm{a}:$ グローブ球の日射吸収率(1.0)、 $\varepsilon$ :グローブ球の放射率(1.0)

I dir: 直逹透過日射光、I difi 、IL_i : i面の桩散透過日射光、長波放射

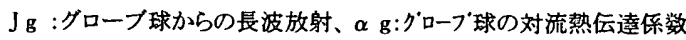

$\alpha \mathrm{g}=0.147 \cdot\left[2.0+0.3(10000 \cdot \mathrm{V})^{0.566}\right]$ (V 第囲気風速 $=0.5 \mathrm{~m} / \mathrm{s}$ とした $)$

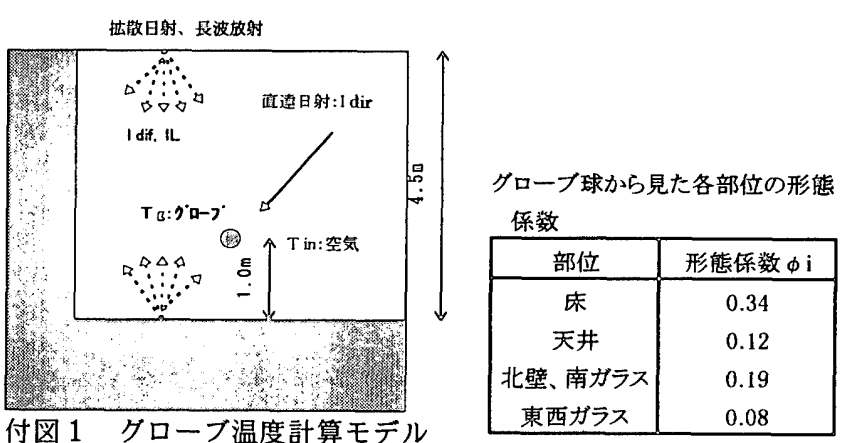

付図 1 グローブ温度計算モデル

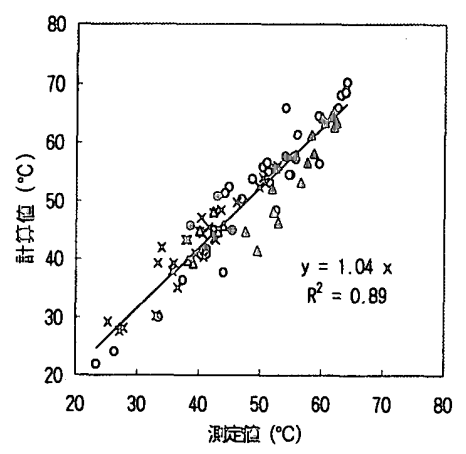

(1):CASE $1 、 O: C A S E 2 、 \times: C A S E 3 、 \triangle:$ CASE $4 、 \triangle: C A S E 5$ 付図 2 グローブ温度の計算結果

（1997年 4 月 7 日原稿受理， 1997年 9 月19日採用決定） 